\title{
Desenvolvimento de um sistema triplex em PCR em tempo real para quantificação de DNA humano em amostras forenses
}

\author{
Development and use of triplex real-time PCR assay for \\ human DNA quantification in forensic samples
}

\author{
Francischini, CW ${ }^{1}$; Sumita, DR ${ }^{1}$; Whittle, MR ${ }^{1}$
}

\begin{abstract}
Francischini, CW; Sumita, DR; Whittle, MR. Desenvolvimento de um sistema triplex em PCR em tempo real para quantificação de DNA humano em amostras forenses. Saúde, Ética \& Justiça. 2013;18(Ed. Especial):72-8.

RESUMO: O DNA extraído a partir de amostras forenses se encontra com frequência em estado de degradação, o que afeta a análise de maneira significativa. Além disso, tais amostras são comumente contaminadas com micro-organismos, de forma que o DNA extraído poderá conter grandes quantidades de material genético não-humano, levando a um valor superestimado da concentração do DNA pelo método padrão de absorbância no UV a $260 \mathrm{~nm}$. A quantificação por PCR em tempo real tem sido aplicada para a quantificação de DNA humano em amostras forenses e alguns kits para esse propósito são atualmente comercializados. Nós descrevemos o desenvolvimento de um sistema para quantificação de DNA humano baseado na utilização de PCR em tempo real para amplificar de forma específica, e no mesmo tubo, sequências presentes nos cromossomos autossômico e $Y$ humanos. A metodologia utiliza "quenchers" BHQ ligados covalentemente a um oligonucleotídeo genérico (antiprimer), capaz de parear com os primers fluorescentes livres de cada um dos alvos e inibir suas fluorescências. A fluorescência aumenta à medida que os produtos são amplificados, possibilitando a captação do sinal pelo equipamento. O sistema também possui um controle interno constituído por uma sequência de DNA sintético, com objetivo principal de indicar a presença de inibidores da reação no material genético extraído. Nós demonstramos que o triplex em questão é uma importante ferramenta para análises forenses, pois permite saber sobre a quantidade e a qualidade do DNA humano existente em uma dada amostra antes que o mesmo seja empregado nos onerosos sistemas de identificação humana, tais como análises de STRs, SNPs e DIPs.
\end{abstract}

DESCRITORES: Quantificação de DNA forense; PCR em tempo real; Identificação humana; Inibidores da PCR; PCR multiplex.

\footnotetext{
1. Genomic Engenharia Molecular.

Endereço para correspondência: Rua Itapeva, 500- Conjunto 5AB. CEP:01332-903- São Paulo, Brasil. e-mail: carlos@genomic.com.br
} 


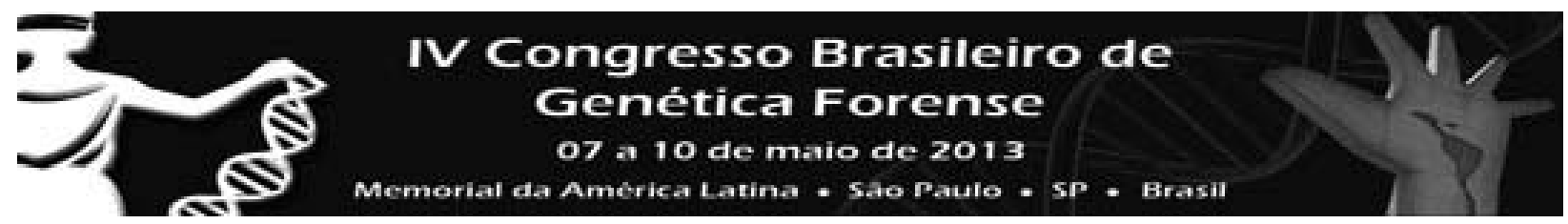

\section{INTRODUÇÃO}

A identificação humana por DNA é comumente baseada na análise de marcadores moleculares presentes no genoma conhecidos como "short tandem repeats" (STRs), "single nucleotide polymorphisms" (SNPs) e "deletion insertion polymorphisms" (DIPs). Os marcadores mais utilizados são os STRs, caracterizados por pequenas sequências de 2 a 6 nucleotídeos repetidas várias vezes em uma determinada região do genoma, chamada de loco. Estas regiões possuem grande interesse forense, pois proporcionam a existência de uma grande variabilidade entre os indivíduos de uma população, visto que o número de vezes que a sequência se repete é variável de pessoa para pessoa ${ }^{1}$. Assim, com a análise de diferentes locos STRs presentes no DNA é possível concluir com mais de $99 \%$ de certeza se determinada amostra biológica pertence ou não a um indivíduo em questão.

A reação em cadeia da polimerase (PCR) seguida de eletroforese capilar é a técnica utilizada para identificação humana por DNA, uma vez que possibilita a análise simultânea de vários locos STRs. Diversos sistemas de análise de STRs estão disponíveis no mercado e exigem uma quantidade de DNA inicial entre 0,1-2,0 ng por reação, sendo a qualidade do DNA usado um fator determinante para o sucesso do resultado ${ }^{2}$. Dessa forma, deve-se considerar que fatores ambientais como altas temperaturas, o tempo, nucleases e umidade contribuem para uma rápida degradação do DNA e que a presença de inibidores da PCR é muito comum nos vestígios, tais como a melanina dos cabelos, ureia e a hemoglobina dos eritrócitos, podendo ser facilmente extraídos juntamente com o DNA da amostra 3,4

Segundo a "DNA Advisory Board" (standard 9.3), a quantificação de DNA humano é um procedimento recomendado para assegurar que a quantidade de DNA presente em uma amostra é indicada para a posterior amplificação por PCR, que o DNA extraído é especificamente humano, e não de outra fonte biológica, e possibilita que apenas uma quantidade mínima de DNA seja utilizada para análise ${ }^{5}$. Em geral, a quantificação das amostras de DNA baseia-se principalmente em dois procedimentos espectrofotométricos: 1) Absorção de luz UV em comprimento de onda a $260 \mathrm{~nm}$, que permite a identificação dos ácidos nucléicos presentes na amostra, mas não discrimina - DNA de possíveis contaminações com RNA provenientes do processo de extração, resultando muitas vezes em um valor superestimado6; 2) Utilização de substâncias fluorescentes capazes de intercalar em DNA dupla-fita, mas não DNA simples-fita ou RNA. Nesse caso, o DNA é analisado em comprimento de onda no espectro visível e a sua concentração na amostra é obtida com mais alto grau de certeza. Em contrapartida, mesmo sendo específico para moléculas de DNA dupla-fita, esse procedimento ainda pode gerar um valor superestimado de concentração, uma vez que não discrimina o DNA humano daquele proveniente de microorganismos contaminantes comumente presentes nas amostras. Além disso, o estado de degradação da amostra, bem como a presença de possíveis inibidores capazes afetar a reação da PCR não podem ser avaliados através dessas técnicas de espectrofotometria.

A correta quantificação do DNA de uma amostra forense permite reduzir custos e agilizar o processo de emissão do resultado. Nesse aspecto, faz-se necessário a elaboração de técnicas e procedimentos capazes de aferir de forma sensível e discriminatória a quantidade de DNA genômico humano obtida de uma amostra forense, bem como a presença de possíveis inibidores da reação de PCR presentes na mesma.

\section{OBJETIVOS}

Desenvolver um sistema de quantificação de DNA que permita discriminar e quantificar de forma específica o DNA humano presente em uma amostra forense, bem como investigar a presença de possíveis inibidores da reação de PCR.

\section{MATERIAL E MÉTODOS}

O sistema desenvolvido baseia-se na utilização de PCR em tempo real para amplificar e quantificar, de forma específica e no mesmo tubo, sequências presentes nos cromossomos autossômico e $Y$ humanos (Tabela 1). Além de uma ferramenta de quantificação, a amplificação do cromossomo masculino pode ser importante para a confirmação da presença de material masculino em amostras femininas. O kit também conta com um controle interno (IPC), constituído por uma sequência de DNA sintético, cujo objetivo principal é analisar a presença de possíveis inibidores da reação presentes no DNA extraído. Os três pares de "primers" sintetizados para os alvos descritos resultam em um sistema triplex. 


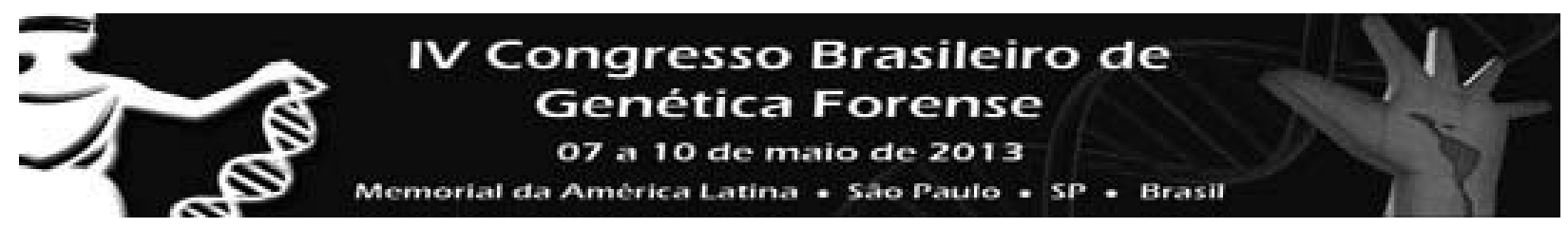

Tabela 1. Alvos usados no sistema de quantificação de DNA humano

\begin{tabular}{ccccc}
\hline Alvo & Gene Alvo & Fluoróforo & Tamanho do amplicon & Ploidia \\
Autossômico & Retinoblastoma 1 & FAM & $110 \mathrm{pb}$ & Diplóide \\
Cromossomo Y & DAZ & Texas-Red & $110 \mathrm{pb}$ & Haplóide \\
IPC & DNA sintético & Cy5 & $110 \mathrm{pb}$ & $---{ }^{---}$ \\
\hline
\end{tabular}

A química escolhida para o sistema baseiase na utilização de "quenchers" BHQ ligados covalentemente a um oligonucleotídeo genérico (antiprimer), capaz de parear com os "primers" fluorescentes de cada um dos alvos (Tabela 1) e inibir a fluorescência dos mesmos. A fluorescência aumenta à medida que os produtos são amplificados, possibilitando a captação do sinal pelo equipamento (Figura 1).

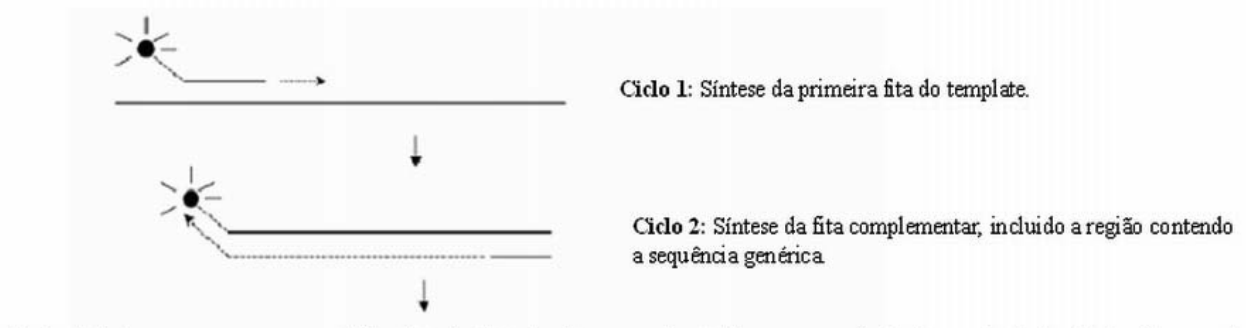

Diminuição datemperatura para permitir a ligação do anti-primer aos primers livres e cạtação da fluorescência das duplas-fitas geradas.

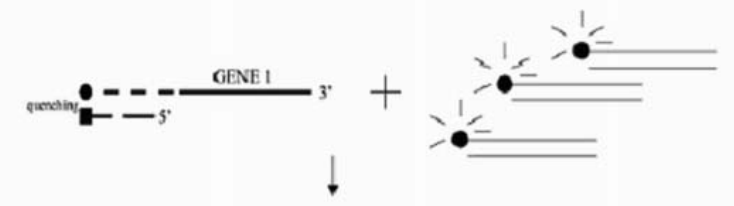

Repetição por 40 ciclos. A captação da fluorescência aumenta à medida que os pordutos são gerados.

Figura 1. A cada final de ciclo, a temperatura da reação é diminuída para permitir a ligação do antiprimer aos oligonucleotídeos marcados livres. O antiprimer não é capaz de ligar aos produtos de PCR dupla-fita, permitindo que a amplificação dos produtos com primers marcados com FAM ou Texas Red resulte em um aumento exponencial da fluorescência ${ }^{7}$

Todos os reagentes necessários para a amplificação dos 3 alvos foram reunidos em dois tubos para agilizar o processo. O tubo 1 é constituído por uma mistura de $\mathrm{MgCl}_{2}$, deoxinucleotídeos trifosfatos e Taq DNA polimerase em solução tampão apropriada, enquanto que o tubo 2 contém "primers" fluorescentes "Foward" e "Reverse" para amplificação dos 3 alvos, o antiprimer contendo o quencher BHQ-2 e a referência passiva Cy3. As reações foram feitas com adição de 25 uL do tubo 1 a 3 uL do tubo 2 e 2 uL da curva padrão ou da amostra forense a ser analisada. $O$ equipamento utilizado foi o Applied Real-time PCR 7500 e o programa foi $95^{\circ} \mathrm{C}$ por 5 minutos, seguido de 40 ciclos de $95^{\circ}$ por 15 segundos, $60^{\circ} \mathrm{C}$ por 60 segundos e $50^{\circ} \mathrm{C}$ por 45 segundos.

\section{DISCUSSÃO}

O National Institute of Standards and Technology (NIST) dos Estados Unidos comercializa um material de referência certificado (MRC), específico para quantificação de DNA humano pela $\mathrm{PCR}^{8}$. Para gerar uma amostra de DNA de referência para o sistema, DNA genômico foi extraído a partir de $3 \mathrm{~mL}$ de sangue colhido com anticoagulante EDTA ${ }^{9}$. A amostra masculina obtida foi então quantificada em equipamento NanoDrop 3300 Fluorospectrometer, a partir de uma curva padrão feita com diferentes concentrações da amostra NIST A, constituída por DNA genômico humano de um único indivíduo do sexo masculino ${ }^{8}$. O DNA extraído foi então diluído a uma concentração final de $50 \mathrm{ng} / \mathrm{uL}$ e utilizado em diluições seriadas na proporção de 1:5 (Tabela 2). 


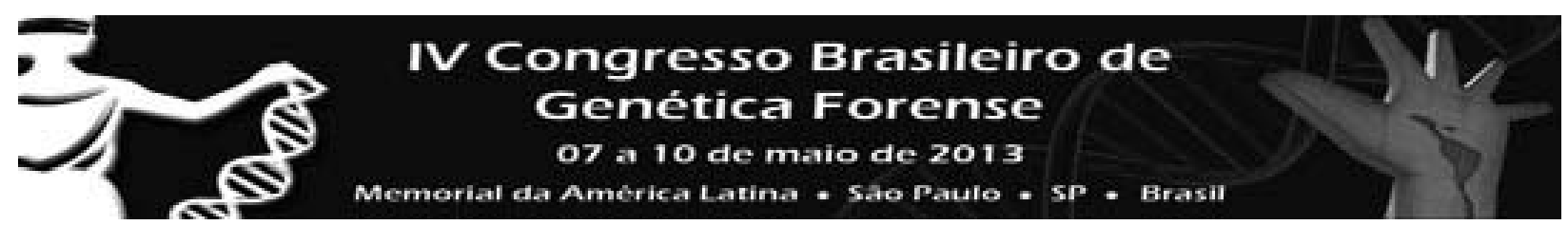

Tabela 2. Diluições seriadas do DNA controle para composição da curva padrão. O DNA padrão a $50 \mathrm{ng} / \mathrm{uL}$ foi quantificado a partir do padrão de DNA NISTA obtido pelo National Institute of Standards and Technology

\begin{tabular}{cccc}
\hline Tubo & Volume do DNA $(\mathbf{5 0} \mathbf{n g} / \mathbf{u L})$ & Buffer TE & Concentração Final \\
1 & Não diluído & $-32--$ & $50 \mathrm{ng} / \mathrm{uL}$ \\
2 & 8uL tubo 1 & $32 \mathrm{uL}$ & $10 \mathrm{ng} / \mathrm{uL}$ \\
3 & 8uL tubo 2 & $32 \mathrm{uL}$ & $2 \mathrm{ng} / \mathrm{uL}$ \\
4 & 8uL tubo 3 & $32 \mathrm{uL}$ & $0,4 \mathrm{ng} / \mathrm{uL}$ \\
5 & 8uL tubo 4 & $32 \mathrm{uL}$ & $0,08 \mathrm{ng} / \mathrm{uL}$ \\
\hline
\end{tabular}

Um volume de 2 uL de cada diluição foi usado em cinco reações para gerar uma curva padrão para os alvos RB1 e DAZ. O gráfico obtido para o IPC indica o comportamento do controle interno em diferentes concentrações de DNA (Figuras 2 e 3).
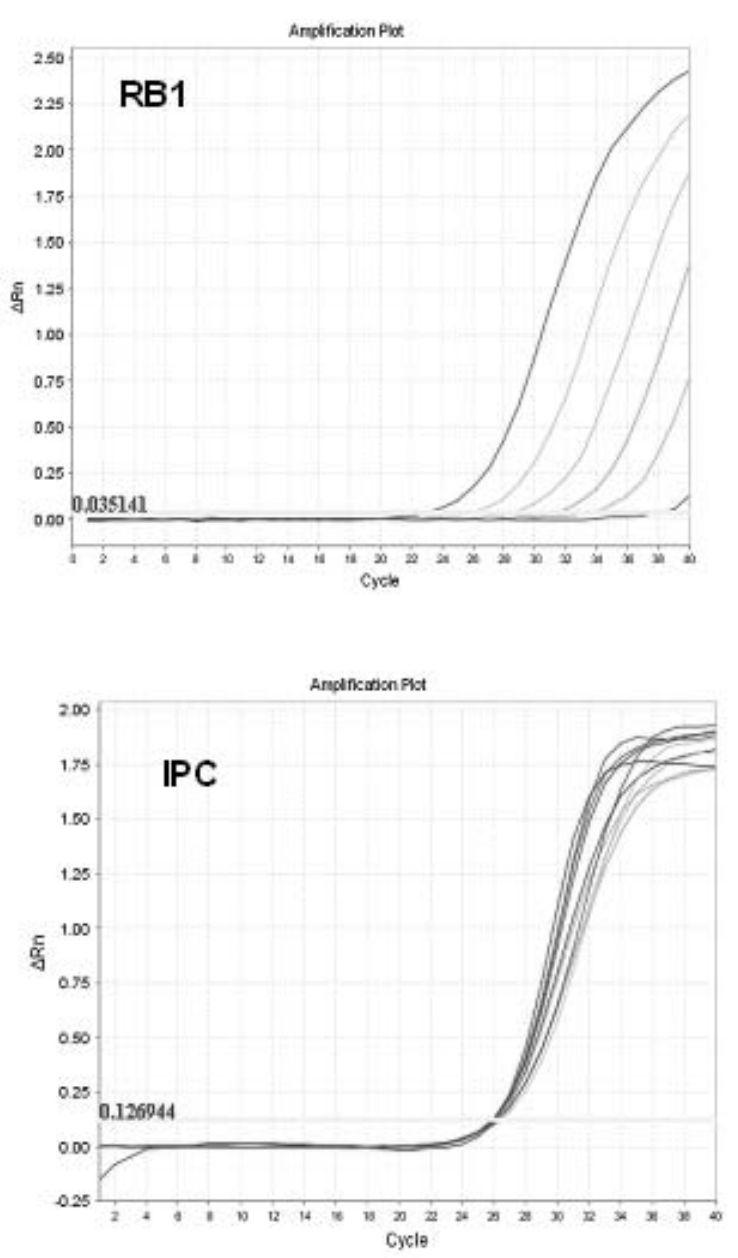

A validação do sistema foi feita com amostras de DNA humano de concentrações previamente determinadas por espectrofotometria. As amostras foram provenientes de três diferentes fontes: NIST, kits comerciais de identificação humana e amostras

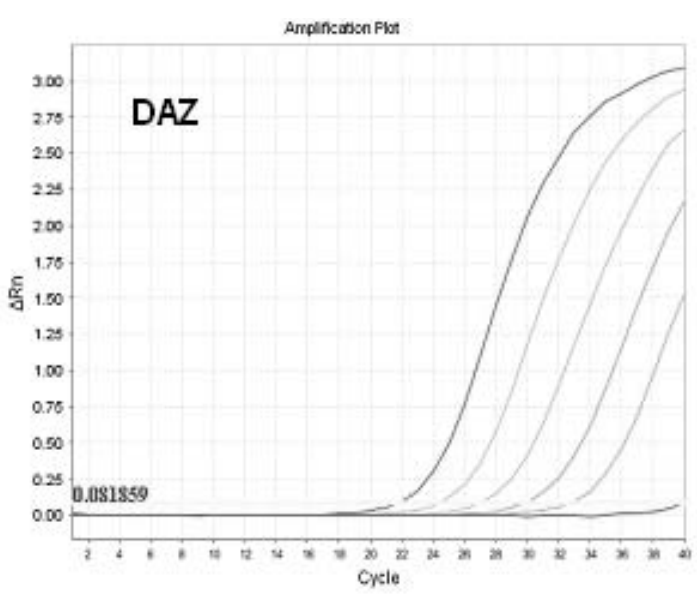

Figura 2. Gráficos esperados para as reações triplex feitas com os pontos da curva padrão. As linhas nos gráficos RB1 e DAZ são, respectivamente, os pontos de 50ng/uL, 10ng/uL, 2ng/uL, 0,4ng/uL, 0,08ng/uL e NTC. Todas as reações foram feitas em duplicata

quantificadas em Nanodrop 3300 Fluorospectrometer. Os resultados mostraram que o que o sistema é eficiente para quantificação em ambos os alvos analisados, além de apresentar poder de discriminação entre DNA feminino e masculino (Tabela 3). 

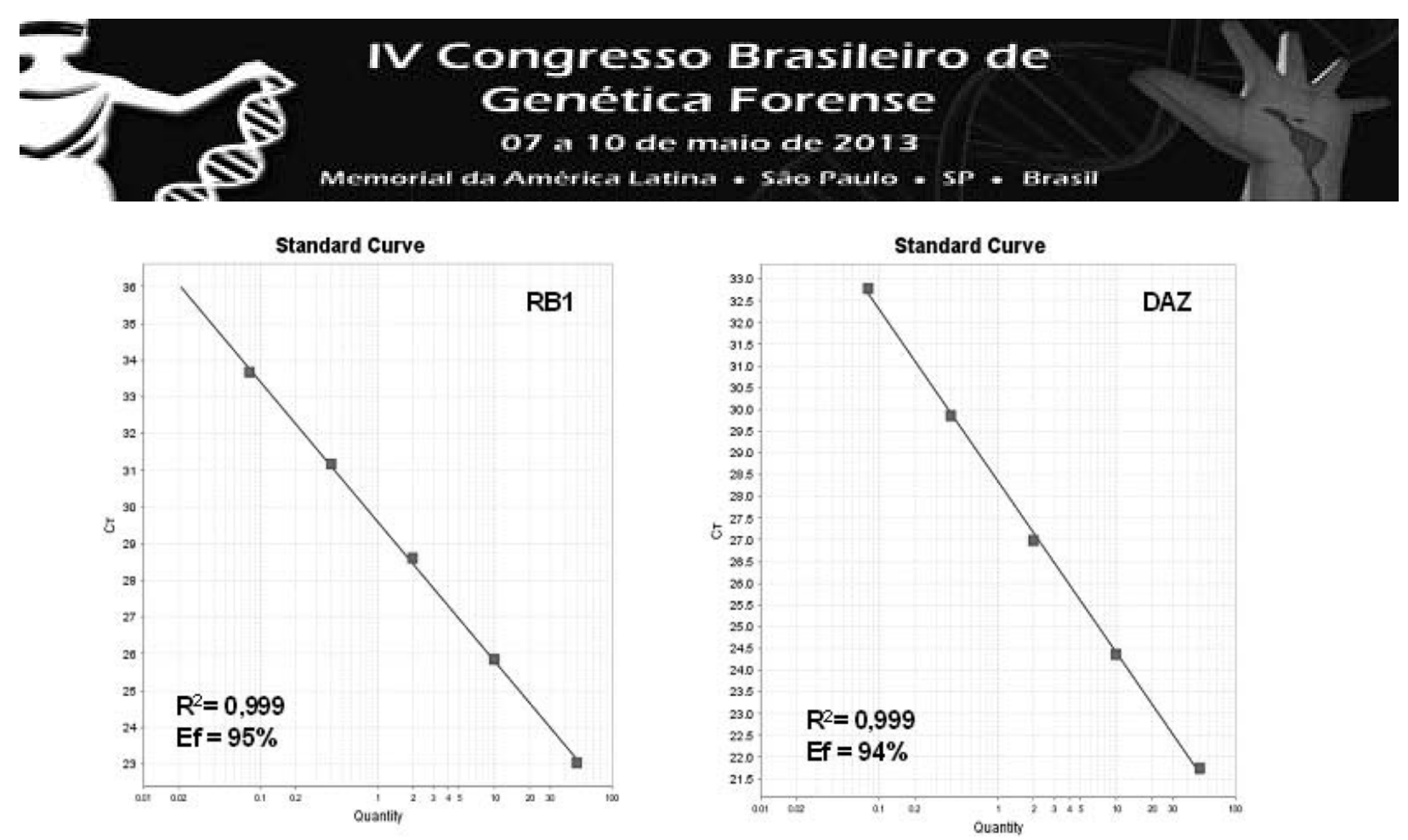

Figura 3. Curvas padrão para os alvos RB1 e DAZ. Os pontos em vermelho referem-se, respectivamente, às concentrações de 50ng/uL, 10ng/uL, 2ng/uL, 0,4ng/uL, 0,08ng/uL

Tabela 3. Amostras usadas como "template" nas reações de validação do sistema de quantificação

\begin{tabular}{|c|c|c|c|c|}
\hline Nome & Descrição & Concentração & $\begin{array}{l}\text { Concentração } \\
\text { (Cromossomo Y) }\end{array}$ & $\begin{array}{l}\text { Concentração } \\
\text { (Autossômico) }\end{array}$ \\
\hline Amostra $1^{a}$ & DNA masculino & $0,1 \mathrm{ng} / \mathrm{uL}$ & 0,05 & 0,08 \\
\hline Amostra $2^{\mathrm{b}}$ & DNA masculino & $0,29 \mathrm{ng} / \mathrm{uL}$ & 0,13 & 0,14 \\
\hline Amostra $3^{a}$ & $\begin{array}{l}\text { DNA de múltiplos homens e } \\
\text { mulheres }\end{array}$ & $2 n g / u L$ & 0,28 & 1,69 \\
\hline Amostra $4^{a}$ & DNA masculino & 2ng/uL & 0,18 & 0,94 \\
\hline Amostra $5^{a}$ & DNA feminino & $13,5 \mathrm{ng} / \mathrm{uL}$ & 0 & 7,64 \\
\hline Amostra $6^{a}$ & DNA masculino & $16 \mathrm{ng} / \mathrm{uL}$ & 6,15 & 9,66 \\
\hline Amostra $7^{a}$ & DNA feminino & $22 n g / u L$ & 0 & 26,4 \\
\hline Amostra NIST $A^{c}$ & $\begin{array}{l}\text { DNA masculino de um único } \\
\text { indivíduo }\end{array}$ & $5 n g / u L$ & 5,1 & 8,75 \\
\hline Amostra NIST $B^{c}$ & DNA de múltiplas mulheres & $5 n g / u L$ & 0 & 8,96 \\
\hline Amostra NIST $\mathrm{C}^{\mathrm{c}}$ & $\begin{array}{l}\text { DNA de múltiplos homens e } \\
\text { mulheres }\end{array}$ & $5 n g / u L$ & 3,76 & 10,2 \\
\hline
\end{tabular}

${ }^{a}$ Amostras padrões fornecidas com kits de identificação humana.

${ }^{\mathrm{b}}$ Amostras quantificadas em nanodrop.

${ }^{\mathrm{c}}$ Amostras adquiridas com concentrações previamente determinadas por espectrofotometria a $260 \mathrm{~nm}^{8}$.

A sensibilidade do sistema na presença de inibidores foi avaliada a partir de amostras contendo quantidades crescentes de hematina, uma molécula encontrada nas células vermelhas do sangue $^{10}$ (Figura 4). O comportamento do controle interno IPC e suas interpretações estão descritos na Tabela 4.

\section{CONCLUSÃO}

O sistema descrito apresenta diversas vanta- gens em relação aos métodos de quantificação espectrofotométricos, como a utilização de um pequeno volume de amostra sem a necessidade de etapas de diluição, limite de detecção na ordem de picogramas, especificidade para o DNA humano e capacidade de discriminação entre o material genético masculino ou feminino. A quantificação do DNA a partir de PCR em tempo real permite ampliar a certeza de sucesso na análise dos STRs, uma vez também possibilita a identificação da presença inibidores da reação comumente encontrados após as extrações. 

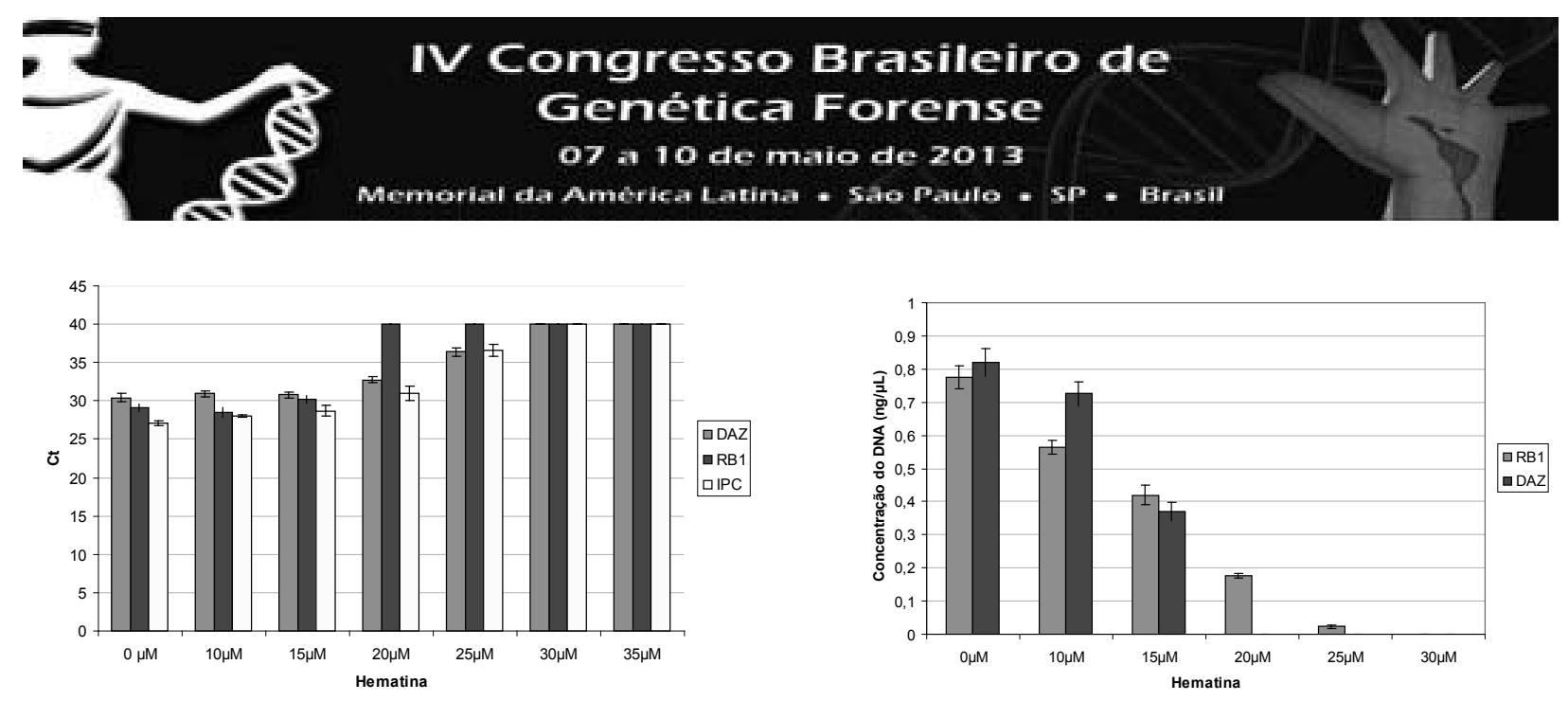

Figura 4. Amostras de concentração $1 \mathrm{ng} / \mathrm{uL}$ de DNA genômico masculino humano foram geradas com diferentes concentrações do inibidor hematina. A) Cts observados para os alvos RB1, DAZ e IPC. B) Quantificação obtida das amostras em cada situação de inibição.

Tabela 4. Interpretações com base na amplificação do controle interno da reação

\begin{tabular}{ccc}
\hline Alvos DAZ ou RB1 & IPC & $\begin{array}{c}\text { Interpretação } \\
\text { Sem amplificação }\end{array}$ \\
$\begin{array}{c}\text { Sem amplificação } \\
\text { Amplificação com baixo Ct e } \\
\text { alto } \Delta \text { Rn }\end{array}$ & Amplificação & $\begin{array}{c}\text { Resultado negativo- DNA } \\
\text { humano não encontrado } \\
\text { Resultado inválido }\end{array}$ \\
Amplificação com alto $\mathrm{Ct}$ & Sem amplificação ou Ct alto $(>29)$ & $\begin{array}{c}\text { Resultado do IPC inconclusivo } \\
\text { Presença de inibidores na } \\
\text { reação }\end{array}$ \\
\hline
\end{tabular}

Francischini, CW; Sumita, DR; Whittle, MR. Development and use of triplex real-time PCR assay for human DNA quantification in forensic samples. Saúde, Ética \& Justiça. 2013;18(Ed. Especial):72-8.

ABSTRACTS: It is usual for the human DNA samples encountered in forensic casework to be variably degraded, thus significantly affecting downstream analysis. Furthermore these samples are commonly contaminated with micro-organisms, so that total DNA extraction from the samples will contain variable amounts of non-human DNA, thus difficulting the quantification of the human DNA component by standard UV absorbance at $260 \mathrm{~nm}$. It has become almost routine to quantify the human DNA component of forensic DNA extractions by using realtime PCR (qPCR) and commercially sold kits are presently available for this. We describe the development and use of a single-tube triplex qPCR assay for quantifying human DNA in extracted forensic samples prior to amplification of STR loci. Two nuclear loci are targeted, one being autosomal and the other situated on the $\mathrm{Y}$ chromosome. The third target is a synthetic oligonucleotide which is present during amplification and which acts as an internal control for amplification inhibition. Three different common fluorophores are used and the chemistry is based on a quencher molecule linked to an antiprimer which suppresses fluorescence until the generation of sufficient amplicon during amplification overcomes the quenching. The amplicon sizes are approximately $80 \mathrm{bp}$. Signal generation is monitored in a qPCR instrument in the presence of a passive reference dye. We demonstrate that the qPCR triplex in question is an important tool for our forensic analyses, because it allows us to obtain information concerning the quantity and quality of the human DNA in our extracted samples, prior to using the costly human identification reagents, such as in the analysis of STRs, SNPs and DIPs.

KEYWORDS: Forensic DNA quantification; Real-time PCR; Human identification; PCR inhibitor; Multiplex PCR.

\section{REFERÊNCIAS}

1. Butler JM. Fundamentals of Forensic DNA Typing. San Diego: Elsevier Academic Press, 2010.
2. Frank WE, Llewellyn BE, Fish PA, Riech AK, Marcacci TL, Gandor DW, Parker D, Carter RR, Thibault SM. 


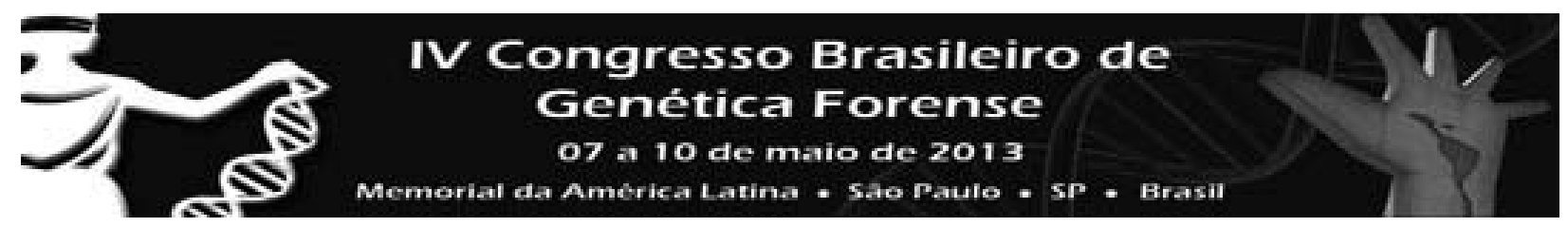

Validation of the AmpFISTR ProWler Plus PCR ampliWcation kit for use in forensic casework. J. Forensic Sci. 2001;46:642-646.

3. Abu Al-Soud W, Radstrom P. Effects of amplification facilitators on diagnostic PCR in the presence of blood, feces, and meat. J Clin Microbiol. 2000;38(12): 4463-4470.

4. Butler JM. Forensic DNA typing: biology, technology, and genetics of STR markers. 2nd ed. Elsevier Academic Press; 2005.

5. DNA Advisory Board. Quality Assurance Standards for Forensic DNA Testing Laboratories. Vol. 2. Forensic Science Communications: 2000.

6. Sambrook J, Russell, DW. Molecular Cloning: a Laboratory Manual. 3rd. ed. New York: Cold Spring Harbor Laboratory Press: Cold Spring Harbor; 2001.

7. Li J, Wang F, Harvey M, Matthew HK, Lyndsay
$H$, Elizabeth $M$, Lilin W,G. Mike M. Antiprimer Quenching-Based Real-Time PCR and Its Application to the Analysis of Clinical Cancer Samples. Clinical Chemistry. 2006;52(4):624-633.

8. Kline MC, Duewer DL, Travis JC, Smith MV, Redman JW, Vallone PM, Decker AE, Butler JM. Production and certification of NIST Standard Reference Material 2372 Human DNA Quantification. Standard. Anal. Bioanal. Chem.2009; 394:1183-1192.

9. Miller OJ, Dykes DD, Polesky HF. A simple salting out procedure for extraction DNA from human nucleated cells. Nucleic Acids Research.1988:16-1215.

10 Akane A, Matsubara K, Nakamura H, Takahashi S, Kimura K. Identification of a heme compound copurified with deoxyribonucleic acid (DNA) from bloodstains, a major inhibitor of polymerase chain reaction (PCR) amplification. J Forensic Sci. 1994;34:362-72. 